\title{
Implementasi Perbankan Syariah Di Malaysia Dan Indonesia
}

\section{Satria Darma}

Sekolah Tinggi Agama Islam Negeri Mandailing Natal

Corresponding Author: satriadarmamuhammad@gmail.com

\section{ABSTRACT}

This study aims to analyze the implementation of Islamic banking in Malaysia and Indonesia. This research uses exploratory study method, descriptive analysis in analyzing secondary data related to these problems. The results show that the difference in product diversity and Islamic bank contracts in the two countries is due to several factors such as the economic system adopted by a country, the school of thought or school of thought used by the majority of people in each country, the position of Islamic banks in the law and the approach to law. selected product development.

Keywords

Implementation, Islamic Banking, Akad Modification

\section{PENDAHULUAN}

Konsep perbankan syariah disasarkan atas ekonomi secara Islam yang berlandaskan kepada al-Quran dan Hadist. Islam sangat berhati-hati terhadap transaksi dalam bidang ekonomi, karena didalamnya mengandung unsurunsur yang mengarah kepada kebathilan (Hayat, 2014).

Bank Syariah pada berbagai negara bisa memiliki persamaan dan perbedaan karena beberapa hal. Perbedaan ini akan tercermin pada penggunaan akad yang berbeda dalam produk dan jasa yang ditawarkan bank syariah. Faktor-faktor yan gmempengaruhi perbedaan tersebut, antara lain: Sistem ekonomi yang dianut oleh suatu Negara, Aliran pemikiran atau mazhab yang dipakai oleh mayoritas masyarakat pada suatu Negara, Kedudukan bank syariah dalam undang- undang, dan Pendekatan pengembangan produk yang dipilih.

Suatu negara dapat menganut system ekonomi islam secara penuh (fully Islamic System), system ekonomi ganda, atau system ekonomi non Islam seperti system ekonomi kapitalis atau sosialis. Negara yang menganut system ekonomi Islam penuh memiliki infrastruktur keuangan Islam yang lengkap dengan undang - undang yang bedasarkan Syariah Islam. Oleh karena itu, perbankan syariah di negara tersebut memiliki lingkungan yang paling cocok untuk beroperasi dan berkembang dengan leluasa sesuai.

Negara yang menganut system ekonomi ganda dapat memilki infrastruktur keuangan Islam yang bervariasi . Infrastruktur keuangan Islam 
yang tidak lengkap akan menghambat dan membatasi ruang gerak perbankan syariah. Selain itu, persaingan head to head dengan bank konvensional memaksa bank syariah bekerja lebih keras, lebih kreatif dan lebih inovatif untuk mendapatkan pangsa pasar. Sementara itu, negara yang menganut system ekonomi non Islam dengan sendirinya akan memiliki infrastruktur keuangan eknomi Islam yang minimal, sehingga perbankaSyariah di negara tersebut harus ekstra kreatif dan inovatif di sekeliling lingkungan yang membatasinya.

Bank Syariah pada Negara yang mempunyai mayoritas penduduk muslim dapat berbeda produk dan jasa yang ditawarkan karena masingmasing negara menganut mazhab yang berbeda contoh negara muslim di Timur Tengah memiliki mazhab yang berbeda dengan negara muslim di Asia. Perbedaan Mazhab menyebabkan perbedaan dalam ketentuan syarih yang diyakini.

Kedudukan bank Syariah dalam undang-undang sangat mempengaruhi ruang gerak bank Syariah di negara tersebut. Bank syariah yang beroperasi di bawah undang-undang perbankan syariah akan lebih leluasa beroperasi secara syariah dibandingkan dengan degan bank syariah yang beroperasi di bawah undang- undang perbankan secara umum.

Kebijakan atau pendekatan pengembangan produk yang dipilih oleh otoritas perbankan syariah iktu menentukan produk dan jasa yang ditawarkan kepada nasabah.. Pendekatan pengembangan produk yang hati-hati terhadap prinsip syariah akan mengarah pada produk dan jasa yang selalu comply to shariah principle sesuai dengan prinsip-prinsip syariah.Konsekuensinya, pengembangan produk jadi lebih lama. Sebaliknya pendekatan produk yang pragmatis dan market driven pada umumnya akan lebih mengarah pada variasi produk yang beraneka ragam seiring dengan produk serupa perbankan konvensional. Pendekatan ini pada umumnya menganut ketentuan-ketentuan syariah yang lebih longgar sehingga instrument dan produk yang dihasilkan kreatif dan inovatif mengikuti permintaan pasar.

Dengan adanya perbedaan-perbedaan tersebut produk, jasa dan instrument keuangan syariah yang ada dan dipasarkan dalam suatu negara mungkin tidak ada dan tidak ditawarkan dengan negara lain karena ulama tersebut berpendapat akad yang dipergunakan tidak sesuai dengan prinsip syariah sesuai dengan mazhab yang dianut oleh negara atau muslim di negara tersebut.

Perbedaan-perbedaan tersebut membuat produk, jasa dan instrument keuangan syariah di dunia sangat divergen, bervariasi dan tidak ada standar. Untuk itu, lembaga keuangan internasional seperti IFSB (Islamic Financial 
Service Board) dan AAOIFI (Accounting and Auditing Organization of Islamic Financial Institution) adalah dua lembaga keuangan Islam yang bertugas untuk melakukan konvergensi, standarisasi produk dan operasi bank syariah secara internasional.

Berdasarkan Uraian di atas, maka perlu lebih jelas dan rinci: (1) Bagaimana gambaran umum, Strategi Pengembangan Perbankan dan Karakteristik perbankan syariah pada negara Malaysia dan Inonesia? (2) Bagaimana kedudukan bank syariah dalam undang-undang pada negara Malaysia dan Indonesia? (3) Bagaimana implementasi dan Pengembangan Produk dan akad pada bank syariah di negara Malaysia dan Inonesia?

\section{METODE PENELITIAN}

Metode yang digunakan dalam penelitian ini menggunakan metode penelitian kepustakaan (library research), yaitu penelitian dengan cara mengumpulkan data-data dan karya tulis ilmiah yang berkaitan dengan obyek pembahasan penelitian dan atau pengumpulan data dengan sifat kepustakaan, atau melakukan kajian mendasar yang dilaksanakan untuk memecahkan permasalahan yang pada dasarnya tertumpu pada kajian kritis dan secara mendalam terhadap bahan-bahan pustaka serta referensi karya ilmiah lainnya yang relevan. Kajian merujuk kepada buku-buku dan karya-karya ilmiah yang berkaitan dengan pencatatan transaksi, akuntansi syariah, serta dalil-dalil penunjang lainnya.

\section{HASIL DAN PEMBAHASAN \\ Malaysia}

Malaysia adalah negara yang terdiri dari berbagai macam suku bangsa denganpemeluk agama yang beragam, terdiri dari Muslim 58 persen, Hindu 8 persen, Kristen 24 persen dan lainnya 10 persen. Namun demikian, agama resmi negara adalah Islam.Oleh karena itu, pemerintah Malaysia mempunyai kewajiban untuk mengakomodasipengembangan lembaga keuangan syariah di Malaysia sesuai dengan agama Islamyang dianut negara dan mayoritas rakyatnya. Atas dasar tersebut Malaysia mulai menerapkan dual economic system dan mengembangkan sistem keuangan dan perbankan syariah sejak 1983.

Malaysia telah menjadi suatu kekuatan Asia Tenggara di industri keuangan syariah global. Perbankan syariah Malaysia yang telah berjalan beberapa dekade terus berevolusi dengan tujuan memenuhi kebutuhan industri global. Inovasi produk juga menjadi isu penting dalam perbankan syariah Malaysia. 


\section{Strategi Pengembangan Perbankan Syariah Malaysia}

Tujuan jangka panjang yang ingin dicapai dalam pengembangan perbankan syariah di Malaysia adalah menciptakan sistem keuangan dan perbankan Islam yang menyeluruh yang beroperasi sejajar dengan sistem perbankan konvensional. Untuk menciptakansistem perbankan yang kokoh diperlukan tiga elemen penting, yaitu: 1). Jumlah pemain yang banyak, 2). Keragaman instrumen yang luas, 3)..Pasar keuangan Islam.

Strategi pengembangan yang dipilih adalah pengembangan secara komprehensif,bertahap, dan pragmatis yang diawali dengan tahapan untuk menciptakan enablingenvironmen dengan mempersiapkan berbagai infrastruktur keuangannya khususnya legal framework. Tahap berikutnya adalah meningkatkan volume dan menciptakan pasar bagi lembaga keuangan syariah sehingga lembaga keuangan syariah dapat berkompetisi. Tahap ketiga adalah menciptakan harmonisasi dan konvergensi denganpasar keuangan syariah internasional sehingga lembaga keuangan syariah Malaysiadapat bersaing di arena internasional.

\section{Karakteristik Perbankan Syariah Malaysia}

Ada berbagai hal yang mencerminkan karakteristik perbankan syariah suatu negara. Beberapa di antaranya adalah : sistem keuangan dan perbankan yang dianut, aliran pemikiran atau madzhab dan pandangan yang dianut oleh negara atau mayoritas muslimnya. Kedudukan bank syariah dalam undang-undang dan pendekatan pengembangan perbankan syariah dan produknya yang dipilih.

\section{Kedudukan Bank Syariah dalam Undang-undang}

Bank syariah di Malaysia berada di bawah undang-undang yang berbeda tergantungdari bentuk institusinya. Bank syariah penuh ( full fledged Islamic bank) berada dibawah undang-undang perbankan syariah atau Islamic Banking Act yang diterbitkantahun 1983. Sementara itu, Islamic windows atau bank konvensional yang menawarkan produk-produk perbankan syariah berada di bawah undang-undang perbankan konvensional. Dengan perbedaan undang-undang yang mengaturnya,operasi full fledged Islamic bank menjadi lebih leluasa daripada Islamic windows terutama dalam penerapan ketentuan-ketentuan Syariah. Selain itu, undang-undangperbankan syariah tahun 1983 merupakan hukum sipil (civil law) sehingga tetap dibawah yurisdiksi pengadilan sipil (civil court).

Keadaan ini mempunyai implikasi bahwadengan undang-undang perbankan syariah tahun 1983 bank syariah dapatmenerapkan nilai-nilai Syariah dalam operasinya, tetapi tidak cukup untuk menutupi undang-undang perbankan konvensional untuk mencerminkan konsep murni dari jual beli (al-bai). Sesuai dengan undang-undang perbankan, bank Islam atau bankkonvensional hanya boleh menyediakan fasilitas pembiayaan. Bank tidak diperkenankan untuk membeli dan menjual aset untuk mendapatkan untung. 


\section{Kedudukan Dewan Syariah}

Otoritas syariah tertinggi di Malaysia berada pada NSAC yang didirikan pada 1 Mei 1997 dan berada dalam struktur organisasi Bank Negara Malaysia (BNM). AnggotaNSAC ditunjuk oleh dewan direktur (board of directors) BNM untuk masa kerja tigatahun dan dapat dipilih kembali untuk periode berikutnya.

\section{Strategi Pengembangan Perbankan Syariah dan Produknya}

Dalam hal strategi pengembangan perbankan syariah dan produk-produknya, Malaysiamemilih pendekatan komprehensif dan pragmatis. Dengan strategi pengembanganyang komprehensif bank syariah berkembang dengan baik di Malaysia karenainfrastruktur pendukung yang diperlukan oleh bank syariah semuanya tersedia.Sementara itu, strategi pengembangan yang pragmatis memungkinkan bank syariah diMalaysia berkreasi dan berinovasi dengan leluasa untuk mengembangkan produk daninstrumen keuangan sesuai dengan permintaan pasar. Hasilnya, perbankan syariahMalaysia memiliki variasi produk dan instrumen keuangan syariah yang beragamdibandingkan dengan produk dan instrumen keuangan syariah di negara lain.Berbagai produk dan instrumen keuangan syariah di Malaysia populer menggunakanakad atau mengandung unsure Bai' Al-Inah dan Bai' Al-Dayn.

Dengan menerapkan kedua akad ini, produk dan instrumen keuangan syariah dapat menyerupai produkdan instrumen keuangan konvensional. Apabila di perbankan konvensional ada kartukredit, maka di perbankan syariah ada kartu kredit Syariah. Apabila di perbankankonvensional ada fasilitas overdraft, maka di perbankan syariah ada overdraft Syariah.Apabila di perbankan konvensional ada instrumen pasar uang jangka pendek, maka diperbankan syariah ada instrumen pasar uang syariah jangka pendek. Demikian seterusnya, sehingga hampir semua produk dan instrumen keuangan konvensionalselalu ada padanannya pada produk dan instrumen keuangan syariah.Dengan strategi pengembangan yang dipilih oleh Malaysia, perbankan syariah di Malaysia berkembang dengan pesat sehingga dalam waktu singkat telah menguasai11 persen pangsa pasar perbankan secara nasional.

\section{Akad Bank Syariah di Malaysia}

Bank syariah di Malaysia menerapkan akad yang bervariasi untuk produk daninstrumen keuangan syariah yang ditawarkan kepada nasabah. Akad-akad tersebut meliputi akad-akad untuk pendanaan, card services jasa kartu',Trade financing' pembiayaan perdagangan, dan banking services 'jasa perbankan', sebagai berikut:

- Pendanaan :Wadiah, Mudharabah

- Pembiayaan : :

- Variable Rate : Ijarah, Kafalah,Wakalah, Bai al-Inah, Bai'al-Dayn, Istishna

- Jasa Perbankan : :Qardh Hasan, BBA, Bai'al-Inah,Ujr; dan

- Instrumen Keuangan Syariah: Baial-Inah, BBA,Murabahah,Mudharabah,Ujr 
Ada beberapa akad khas yang digunakan perbankan syariah Malaysia adalah akad berpola jual beli, yaitu Bai' al-Inah,Bai'; adalah akad jual beli ketika penjual menjual asetnya kepada pembelidengan janji untuk dibeli kembali (sale and buy back) dengan pihak yang sama. Bai' al-Inah adalah penjualan tunai (cash sale) dilanjutkan dengan pembelian kembali dengan tangguh (deferred payment sale/BBA). Dalam akad Bai' alInah kedua belah pihak sebenarnya tidak berniat untukmenggunakan aset sehingga mereka melanggar salah satu prinsip kontrak dalamIslam, yaitu maudu'ul aqdi 'tujuan kontrak' (Sanusi, 2012).

Sebagian besar madzhab utamaberpendapat bahwa Bai' al-Inah tidak sesuai dengan prinsip Syariah sehingga dilarang.Ketidaksesuaian dengan prinsip Syariah dikarenakan Bai' al-Inah digunakan sebagai zari'ah 'cara' atau hilah 'alasan hukum' (legal excuse) untuk melegitimasi riba.

Ad-Dayn, adalah akad jual beli ketika yang diperjualbelikan adalah Dayn atau hutang.Dayn dapat diperjualbelikan dengan harga yang sama, tetapi sebagian besarulama Fiqih (Fuqaha) sepakat bahwa jual beli Dayn atau hutang dengan diskon tidak dibolehkan secara Syariah. Islamic Figh Academy (IFA) yang berkedudukan di Jeddah, yang merupakan badanrepresentatif terbesar dari para ulama dan memiliki representasi dari semua negaraMuslim, termasuk Malaysia, telah menyetujui pelarangan.Bai' al-Dayn secara aklamasi tanpa adanya negara yang menolak.Namun demikian, pada pertemuan kedua 21 Agustus 1996, NSAC secara aklamasi menyetujui untuk menerima prinsip Bai' al-Dayn, yaitu perdagangan hutang, sebagaisalah satu konsep untuk mengembangkan instrumeninstrumen pasar modal Syariah.Dewan Syariah Malaysia (NSAC) berpandangan bahwa hutang sama dengan hartabenda (debt= property). Karena hutang sama dengan harta benda, maka hutangdapat diperjualbelikan dengan harga berapa pun layaknya harta benda. dan $B B A$ (BBA), serta akad berpola sewa, yaitu Variable Rate Ijarah.

Bai' Bithaman Ajil atau BBA adalah akad jual beli murabahah (cost+margin) ketikapembayaran dilakukan secara tangguh dan dicicil dalam jangka waktu panjang,sehingga disebut juga credit murabahah jangka panjang. Pada perbankan Syariah di Malaysia Akad BBA hampir serupa dengan transaksi KPR konvensional, namun dari segi proses dan tahapannya sangat berbeda. Potensi yang mungkin terjadi dari akad ini adalah adanya kesalahan menjalankan dokumentasi dari sisi hukum karena rumah yang dibeli harus dimiliki terlebih dahulu oleh bank yang tidak boleh melakukan balik nama langsung menjadi atas nama konsumen (Sanusi, 2012).

Musyarakah Mutanaqisah adalah akad bagi hasil yang merupakan penyertaan modal secara terbatas dari satu mitra usaha kepada mitra usaha yang lain untuk jangkawaktu tertentu (Muhammad, 2013). Dalam salah satu aplikasinya (seperti yang dilakukan oleh Kuwait Finance House / KFH), akad Musyarakah Mutanaqisah digunakan untuk pembiayaan perumahan dan properti. 
Dalam hal ini, pembiayaan dengan akad Musyarakah Mutanaqisah merupakan bentuk kerja sama kemitraan ketika bank dan nasabah bersama-samamembeli rumah atau properti. Aset tersebut kemudian disewakan kepada nasabahdengan biaya sewa bulanan. Bagian pendapatan sewa nasabah digunakan sebagaipenambahan kepemilikan, sehingga pada waktu tertentu (saat jatuh tempo), rumahatau properti tersebut menjadi milik nasabah sepenuhnya.

\section{Produk Bank Syariah di Malaysia}

Produk dan jasa bank syariah di Malaysia sangat bervariasi dan mencapai lebih dari 40 jenis produk dan jasa keuangan syariah dengan menggunakan akad yang ber variasi juga. Produk dan jasa tersebut meliputi produk dan jasa untuk pendana an,pembiayaan, pembiayaan perdagangan, jasa perbankan, card services' pelayanankartu', treasury, dan instrumen pasar uang.Produk dan jasa tersebut sangat mirip dengan produk dan jasa yang ditawarkan perbankan konvensional.

Penamaan produk dan jasa syariah mengikuti namakonvensional produk dan jasa tersebut dengan menambahkan inisial $i$ di belakangnyayang menunjukkan bahwa produk atau jasa tersebut adalah produk atau jasa yangmenggunakan prinsip syariah (Islamic). Misalnya, tabungan atau savings account diberi nama savings account- $i$, pembiayaan proyek atau project financing diberi nama projectfinancing-i.

\section{Indonesia}

Indonesia adalah negara kepulauan terbesar di dunia yang memiliki beragam sukubangsa, bahasa, dan agama dengan jumlah penduduk 240 juta. Di Indonesia sendiri yang memiliki pemeluk Islam terbesar 87,18\% dari 237.641 .326 penduduk Indonesia.

\section{Strategi Pengembangan Perbankan Syariah Indonesia}

Atas dasar dorongan kebutuhan masyarakat terhadap layanan jasa perbankan syariah,bank syariah pertama berdiri pada tahun 1992. Semenjak itu, pemerintah Indonesiamulai memperkenalkan dual banking system, bank-bank syariah didirikan dan beroperasi berdampingan dengan perbankan konvensional. (Lutfi, 2003) Komitmen Pemerintah dalam usahapengembangan perbankan syariah baru mulai terasa sejak tahun 1998 yangmemberikan kesempatan luas kepada bank syariah untuk berkembang. Tahunberikutnya, kepada Bank Indonesia (bank sentral) diberi amanah untukmengembangkan perbankan syariah di Indonesia. Selain menganut strategi market driven dan fair treatment, pengembangan perbankan syariah di Indonesia dilakukandengan strategi pengembangan bertahap yang berkesinambungan (gradual and sustainable approach) yang sesuai dengan prinsip Syariah (comply toSharia principles).

Perkembangan bank syariah di Indonesia belakangan ini cukup menggembirakan terlebih setelah keluarnya fatwa bunga bank haram oleh komisi fatwa MUI. Pengaruh fatwa tersebut terlihat pada besarnya pelarian 
dana masyarakat dari bank konvesional ke bank syariah sehingga mengakibatkan over likuiditas atau apa yang disebut oleh Adiwarman A Karim seorang pakar perbankan Islam sebagai over heating (Tarigan, 2015).

\section{Karakteristik Perbankan Syariah Indonesia}

Karakteristik perbankan syariah di Indonesia dapat dilihat melalui beberapa hal, yaitu: sistem keuangan dan perbankan yang dianut; aliran pemikiran atau madzhab dan pandangan yang dianut oleh negara atau mayoritas muslimnya; kedudukan banksyariah dalam undang-undang; dan pendekatan pengembangan perbankan syariahdan produknya yang dipilih.

\section{Kedudukan Bank Syariah dalam Undang-undang}

Bank syariah di Indonesia, baik yang berbentuk bank umum syariah atau BUS (full fledged Islamic bank), unit usaha syariah atau UUS ( full branch Islamic bank ), maupunbank perkreditan rakyat syariah atau BPRS, berada di bawah undang-undangperbankan (UU No.10 Tahun 1998). Operasi perbankan dengan prinsip Syariah sepenuhnya diakomodasi oleh undang-undang. Bank syariah di Indonesia dapatmelakukan transaksi berdasar titipan, pinjaman, bagi hasil, jual beli, sewa, dan prinsiplain yang dibolehkan Syariah. Sejalan dengan keinginan untuk menjamin kepastian hukum bagi stakeholders dan sekaligus memberikan keyakinan kepada masyarakat dalam menggunakan produk dan jasa bank syariah, dan setelah melalui proses yang cukup panjang, akhirnya pada tanggal 16 Juli 2008 telah disahkan UU No. 21 Tahun 2008 tentang Perbankan Syariah (Saparuddin, 2015). Dengan demikian, bank syariah di Indonesia merupakanbank universal yang dapat berusaha sebagai consumer banking investment banking merchant banking leasing company investment agent dan sebagai lembaga amilzakat infaq dan sadaqah.Perbedaan operasi antara BUS dan UUS hampir tidak ada, kecuali dalam hal kebebasankebijakan manajemen. BUS merupakan badan usaha sendiri yang memilikiindependensi kebijakan sehingga memiliki otonomi dalam memilih strategi bisnis danpengembangannya. Sementara itu, UUS merupakan bagian dari bank konvensionalinduknya sehingga kurang memiliki kebebasan dalam menentukan kebijakanmanajemen.

\section{Kedudukan Dewan Syariah}

Otoritas syariah tertinggi di Indonesia berada pada Dewan Syariah Nasional MajelisUlama Indonesia (DSN - MUI), yang merupakan lembaga independen dalammengeluarkan fatwa yang berhubungan dengan semua masalah Syariah agama Islam,baik masalah ibadah maupun muamalah, termasuk masalah ekonomi, keuangan, dan perbankan.

Tugas DSN - MUI di bidang keuangan dan perbankan pada prinsipnya tidak berbeda dengan tugas NSAC Malaysia yang merupakan satu-satunya badan otoritas yangmemberikan saran kepada institusi terkait (Bank Indonesia, Departemen Keuangan,atau Bapepam) berkaitan dengan operasi perbankan syariah atau lembaga 
keuangansyariah lainnya, mengkoordinasi isu-isu Syariah tentang keuangan dan perbankansyariah, dan menganalisis dan mengevaluasi aspek-aspek Syariah dari skim atauproduk baru yang diajukan oleh institusi perbankan dan lembaga keuangan syariahlainnya.Keberadaan DSN - MUI di luar struktur bank sentral membuat otoritas fatwa iniindependen, lebih kredibel, dan diakui secara nasional dalam mengeluarkan keputusandan fatwa yang berkaitan dengan masalah-masalah Syariah yang dihadapi olehperbankan dan lembaga keuangan syariah lainnya.

Namun demikian, karena baragamnya urusan yang ditangani oleh DSN - MUI dan tidak adanya spesialisasikhusus di bidang ekonomi, keuangan, dan perbankan syariah, tanggapan DSN - MUIterhadap masalah yang dihadapi oleh lembaga keuangan syariah menjadi kurangresponsif dan terlambat memenuhi kebutuhan pasar.

\section{Strategi Pengembangan Perbankan Syariah dan Produknya}

Dalam hal strategi pengembangan perbankan syariah dan produk-produknya, Indonesia memilih pendekatan yang bertahap dan berkesinambungan (gradual and sustainable) yang sesuai Syariah (comply to Sharia principles) dan tidak mengadopsiakad-akad yang kontroversial. Pendekatan yang bertahap dan berkesinambungan memungkinkan perkembangan yang sesuai dengan keadaan dan kesiapan pelakutanpa dipaksakan serta membentuk sistem yang kokoh dan tidak rapuh. Sementaraitu, pendekatan yang berhati-hati yang sesuai dengan prinsip Syariah menjaminproduk-produk yang ditawarkan terjamin kemurnian Syariah-nya dan dapat diterimamasyarakat luas dan dunia internasional.Dengan strategi pengembangan yang dipilih, perbankan syariah di Indonesia telahtumbuh menjadi salah satu sistem perbankan syariah dalam dual financial system yang paling sesuai dengan ketentuan Syariah.

\section{Akad Bank Syariah di Indonesia}

Akad-akad yang dipergunakan oleh perbankan syariah di Indonesia dalam operasinyamerupakan akad-akad yang tidak menimbulkan kontroversi yang disepakati olehsebagian besar ulama dan sudah sesuai dengan ketentuan Syariah untuk diterapkan dalam produk dan instrumen keuangan syariah yang ditawarkan kepada nasabah.Akadakad tersebut meliputi akad-akad untuk pendanaan, pembiayaan, jasa produk, jasa operasional, dan jasa investasi sebagai berikut:

- Pendanaan:Wadiah, Mudharabah,

- Pembiayaan: Murabahah, Mudharabah, Musyarakah, Mudharabah wal Murabahah, Salam, Istishna, Ijarah Muntahiy Bittamlik (IMBT), Qardh, Rahn, Hawalah,

- Jasa Perbankan:Ujr, Sarf,Kafalah,Wakalah, Mudharabah Muqayyadah

- Instrumen KeuanganSyariah:Wadiah, Mudharabah 
Journal Economy And Currency Study (JECS)

Volume 3, Issue 2, July 2021

Page 111-121

\section{KESIMPULAN}

Bahwa dari sebagian besar produk perbankan syariah yang diamati, pada dasarnya sebagian besar akad yang digunakan dalam transaksi syariah sudah sesuai dengan maqashid syariah. Namun masih terdapat beberapa akad yang mengalami modifikasi sehingga menjadi tidak sesuai dengan maqashid syariah dan terjangkiti semangat kapitalisme.

Modifikasi akad pada berbagai negara bisa berbeda sesuai dengan kebutuhan dan berbagi factor lainnya pada negara tersebut seperti mayoritas umat muslim di suatu negara, regulasi dan lainnya. Perbedaanperbedaan tersebut membuat produk, jasa dan instrument keuangan syariah di dunia sangat divergen, bervariasi dan tidak ada standar.

Sebagai saran bagi institusi perbankan syariah agar dilakukan kajian secara komfrehensip terhadap akad-akad pada perbankan syariah yang kelola sehingga terwujud maksud dan tujuan dari maqashid syariah. Hal tersebut tentunya sangat membawa kemashlatan bagi nasabah dan stakeholder dalam menggapai ridho Allah Swt serta menjadikan Islam dan syariahnya benar-benar dirasakan oleh masyarakat luas dalam menggapai Islam sebagai rahmatan lil 'alamin.

\section{REFERENCES}

Hayat, Globalisasi Perbankan Syariah : Tinjauan Praktik dalam Menghadapi MEA 2015, dalam Jurnal studi Islamika, (Desember 2014).

Diana, Setiawati, Sistem Informasi Akuntansi, (Yogyakarta: Andi, 2011) Kamus Besar Bahasa Indonesia, Jakarta.

Ali Hamdan, 2017, Pengertian Implementasi Secara Umum, https:/ / alihamdan.id/implementasi/ diakses tanggal 11 Juni 2021.

A. Wangsawidjaja Z., Pembiayaan Bank Syariah, (Jakarta: PT Gramedia Pustaka Utama, 2012).

Edy Wibowo, dkk, Mengapa Memilih Bank Syariah?, (Bogor: Ghalia Indonesia cet.I, 2005).

Undang-Undang No. 21 tahun 2008 tentang Perbankan Syariah.

Mahmood Mohamed Sanusi, Islamic Banking and Finance Shari'ah and Legal: Issues and Challenge, (Selangor: Aslita Sdn. Bhd, 2012).

Mahmood Mohamed Sanusi, The Role of Khiyar Al-'Ayb in Al-Bay'Bithaman Ajil Financing, (Selangor: Aslita Sdn. Bhd, 2012).

Syaik al- Lamah Muhammad, Fiqih Empat Mazhab.

"Penduduk Menurut Wilayah dan Agama yang Dianut".Sensus Penduduk 2010. Jakarta, Indonesia: Badan Pusat Statistik. 15 May 2010. Islam 207176162 (87,18\%), Kristen 16528513 (6,96), Katolik 6907873 (2,91), Hindu 4012116 
Journal Economy And Currency Study (JECS)

Volume 3, Issue 2, July 2021

Page 111-121

(1,69), Buddha 1703254 (0,72), Kong Hu Cu 117091 (0,05), lainnya 299617 $(0,13)$, tidak terjawab $139582(0,06)$, tidak ditanyakan $757118(0,32)$, total 237641326.

Lutfi, Jejak-Jejak Ekonomi Syariah, (Jakarta: Senayan Abadi Publising, 2003)

Azhari Akmal Tarigan, Dari Etika Ke Spiritual Bisnis: Telaah Isu-isu Aktual dan Masa Depan Pendidikan Tinggi Ekonomi Islam, Cet II, Medan: IAIN Press, , 2015.

Saparuddin, "Standar Akuntansi Bank Syariah Di Indonesia (Analisis Terhadap Konsistensi Penerapan Prinsip Bagi Hasil), (Desertasi, PPS-UINSU, Medan, 2015) 